\title{
Investigating legal information in commercial websites: the Terms and conditions of use in different varieties of English
}

\section{Federica Scarpa}

University of Trieste, Italy

fscarpa@units.it

The Terms and conditions of use which are embedded in commercial websites provide a standardised legal model based in common law which exemplifies the increasingly influential role that English plays in international and intercultural commercial and legal settings, but also how deeply rooted legal knowledge is in socio-cultural values and national cultures. Using a small monolingual corpus of Terms and conditions of use drafted in English and embedded in the commercial websites from different countries of origin and legislations based both on common law and civil law, the paper investigates the extent to which different layout/content and language features are displayed by: (1) ELF Terms and conditions translated from different languages/legislations, and (2) ENL non-translated Terms and conditions drafted in different 'core' varieties of English. The aim is to show that the English intralingual variation of this highly structured and conventionalised legal format reflects in fact the existing disparities in legal practice among various national legislations, even among systems belonging to the common law family. International legal models such as the one investigated should consequently be considered as "globally-relevant STs" (Adab, 1998, p. 224), that is, flexible text formats that have been adopted by most countries but at the same time allow for local sociocultural aspects to influence the construction of legal discourse.

\section{Introduction}

Legal knowledge is deeply rooted in socio-cultural values and national cultures. At the same time, by creating the need to translate legal content from one national legal system/language into another, globalisation has brought about transnational legal frameworks which tend to diminish the importance of national legislations. The Terms and conditions of use in commercial websites not only can be taken as an example of the increasingly influential role that English - both ENL (English as a Native Language) and ELF (English as a Lingua Franca) - plays in international and intercultural commercial and legal settings, but also instantiate rather effectively two such opposing tendencies. 
Notwithstanding the fact that the common-law origin of the Terms and conditions should provide with similar standardised formats and conventional formulas the legal information embedded in commercial websites drafted in English, this legal model seems to exemplify particularly well also the difficulties posed by legal-content mediation in such international legal settings.

This small-scale exploratory study builds on previous research on a contrastive analysis of English, German and Italian disclaimers in commercial websites (Magris \& Scarpa, 2013) and Spanish original and localised legal information in corporate websites (Jiménez-Crespo, 2011). The main hypothesis is that, even within the English language, the Terms and conditions of use of a website reflect in fact the existing disparities in legal language and practice among different national legislations, whether based on common law or civil law.

After a brief second and third section illustrating, respectively, the information typically contained in this highly structured and conventionalised format and the corpus used for the study, the remaining sections (4-6) will present the results of a contrastive analysis of: (1) the ELF translated Terms and conditions drawn from the websites of three international car manufacturers from different countries with legislations based on civil law (France, Germany and Italy), and (2) 24 ENL nontranslated Terms and conditions drafted in the 'core varieties' of English used in eight native-English countries broadly sharing the same legal system rooted in common law; these ENL documents were drawn from the national websites of the same three international car manufacturers in those native-English eight countries. Methodologically, the two separate categories provided by the ELF translated and the ENL non-translated Terms and conditions were contrasted both within themselves and against one another mainly at the level of layout/contents (4 and 5) but also by selecting some features which characterise legal English in general and the legal English of Terms and conditions of use in particular (6).

\section{The Terms and conditions of use: a general description}

Every website should contain the terms and conditions governing the policies adopted concerning the access and use of the website by visitors. Such information can be found by clicking a button - usually at the bottom of each page of the site - variously called "Legal", "Terms of use", "Terms and conditions", "Legal notes", "Conditions of Use", "Disclaimer" etc. The term "Disclaimer" should, strictly speaking, refer only to the terms of the contract which seek to exclude or limit liability for breach of contract, while the expression "Terms and conditions of use" should refer, more generally, to the legal information governing the relationship to the website of the user, who is expected to comply with and be bound by it. Often, however, the two terms are used 
interchangeably because the information provided in the Terms and conditions generally deals with the exclusion or limitation of liability concerning the following five issues (see www.disclaimer.de/disclaimer.htm):

- The content of the website: the author reserves the right not to be responsible for the topicality, correctness, completeness or quality of the information provided and rejects any liability claims regarding damage caused by the use of such information;

- The contents linked and referred to from the pages of the website: the author is not responsible for any contents linked or referred to from the website's pages and rejects any liability claims regarding damage caused by the use of information presented in the linked pages;

- The copyright for the material contained in the website and the use of copyrighted material: (1) the author did not intend to use any copyrighted material for the website; (2) the copyright for any material created by the author is reserved and any duplication or use of objects such as images, diagrams, sounds or texts in any type of publications is not permitted without the author's agreement;

- The legal validity of the disclaimer, which is to be regarded as an integral part of the website;

- In websites which collect personal information, the use of the personal data (email addresses, name, addresses) provided voluntarily by visitors, that is, the Privacy policy.

As regards the issue of the use of personal data, while in many countries providing a website with a legal section is not compulsory by law, the protection of privacy and personal identity has become compulsory in most countries. In the European Union, for example, the European Parliament and Council Directive 95/46/EC of 24 October 1995 on the protection of individuals with regard to the processing of personal data and on the free movement of such data has become the reference text for all the laws on the protection of personal data of the EU members. In many websites the Privacy Policy is dealt with in a completely separate document from the one containing the Terms and conditions of use for the visitors of a website. This fundamental separation between the two legal issues was at the root of the decision not to include the Privacy policy pages in the analysis, whether the information on the use of personal data was either contained in a separate document or included in the Terms and conditions. 


\section{The Corpus}

The small-scale monolingual corpus (21,061 running words and 2,153 types) used to investigate the extent of the language variation of ELF and ENL Terms and conditions of use is made up of 27 documents from 25 websites of the three car manufacturers Fiat, Renault and Volkswagen (Table 1), which were collected in August 2012. Of these 27 documents, 3 were English translations from, respectively, Italian, French and German that were embedded in the official international websites of Fiat (www.fiat.com), Renault (www.renault.com) and Volkswagen (en.wolkswagen.com). The total number of words of this ELF subcorpus of translations is 4,129 (980 types), whilst the ENL subcorpus consists of 16,932 words (1,890 types), making up 24 documents downloaded from 22 sites of a total of 8 different native-English countries: Australia, Canada, India, ${ }^{1}$ Ireland, New Zealand, South Africa, United Kingdom and United States. Of the 22 ENL websites, 8 were Fiat's (Australia-Fiat Commercial, Australia-Fiat500/Chrysler, Canada, India, Ireland, South Africa, UK and US), 6 were Renault's (Australia, Canada, India, Ireland, South Africa and UK) and 8 were Volkswagen's (Australia, Canada, Ireland, New Zealand, South Africa, UK and US).

Besides the ELF and ENL subcorpora, the corpus has also been divided in three subcorpora made up of the Fiat, Renault and Volkswagen Terms and conditions, both ELF and ENL. These subcorpora are of different sizes $(4,861,6,370$ and 9,830 running words/tokens, respectively) because not only they contain texts of differing lengths but also do not all feature the 8 native-English countries considered in the study. As an example of the varied and often complex motivations for the lack of uniformity of the three subcorpora, let us take the Fiat subcorpus, where the main reason lying behind the two different legal documents uploaded on two different Australian websites (www.fiatcommercial.com.au and www.chrysler.com.au) is the strategic global alliance the Italian car manufacturer formed with US giant Chrysler in 2010 following Chrysler's bankruptcy. The takeover has homogenised the legal notes not only of Fiat Australia, but also of Fiat US and Fiat Canada, where Fiat is a registered trademark used under license by Chrysler Group LLC and Chrysler Canada. Consequently, the very short (65 words) document available in the Fiat US website (www.fiatusa.com/en) by clicking the Legal, Safety and Trademark information button is exactly the same as that available by clicking the button by the same name in the Chrysler Group LLC's website both in the US (www.chrysler.com/en/) and in Australia (www.chrysler.com.au/), the latter providing a link also to the Fiat Australia site.

Besides removing from the corpus all the documents and/or sections of the Terms and conditions dealing with the protection of personal data and, in some cases (e.g., Renault UK), the related information on the users' registration to the website and social media, the 
corpus was also expunged of all the sections referring to country-specific offers/services (e.g., descriptions and recommended retail prices of new vehicles, sale of used vehicles, car rental contracts, financial services, promotions). The very different lengths of the texts making up the corpus and the very small scale of the corpus, especially of the ELF subcorpus, meant that the corpus was analysed mainly manually.

\section{The three ELF documents: Layout/Contents}

The first step in the analysis was to contrast, across the three ELF subcorpora, the Terms and conditions drawn from the Fiat, Renault and Volkswagen (VW) international websites in English (www.fiat.com, www.renault.com/en and en.volkswagen.com); these ELF documents were all three translations of source texts respectively in Italian, French and German embedded in each manufacturer's national site (www.fiat.it; www.renault.fr; www.volkswagenag.com). A comparison of the layouts of these three documents (Table 2) shows how little they have in common in the following three categories: (1) name of the button at the foot of each page of the websites linking to the Terms and conditions ("Web Privacy"; "Legal information"; "Legal statement"); (2) title of the legal document containing the Terms and conditions ("Privacy - Web Privacy Policy"; "Legal information \& Contributions. Legal information"; "Legal Details"); and, most significantly, (3) layout of the document in terms of the number, titles and contents of the clauses containing an exclusion/limitation of liability for the use of the site (only 4, unnumbered, clauses in the Fiat website vs. a total of 14 in the Renault and 13 in the VW sites, in both cases numbered).

The differences in general layout/content across the three ELF translated documents show that they are all close translations of the respective source-language legal documents and therefore that each translation reflects to a greater or lesser extent the specific legal reality that produced its respective source text. In the localisation process of web pages, this is in line with the requirement that legal texts be translated faithfully to the source text, as opposed to the adaptation to the sociocultural context of the end users required for all the other texts, because they relate to the legal context of the country of the source text (JiménezCrespo, 2011, p. 6). However, these being internationalised sites and English being the lingua franca of international trade and a major language of international legal contexts, what these three translations ultimately show is a different awareness on the part of the drafters of the original Italian, French and German texts of the need to adjust the layout and contents of the source text to the international conventions of this legal model, the highly standardised format of which is testified by the existence even on the Web of many ready-made templates. ${ }^{2}$ 
Looking more closely at the layouts of the three ELF translated documents in Table 2, it is the document in the Fiat international site which stands out most. As stated in its title ("Privacy - Web Privacy Policy") and in the button to access it (Web Privacy), the document deals predominantly (more than 80 per cent) with the processing of personal data, with only a very small portion ( 282 words) referring to the exclusion/limitation of liability for the contents of the website, as compared to the Renault and VW ELF translated documents (2,634 and 1,213 words). Somewhat ironically, a disclaimer about the accuracy of the information provided in the website that was contained in the Italian original document was in fact omitted from the Fiat ELF translation, which incidentally is also the only one of the three not to contain any reference to the applicable law in case of dispute regarding the Terms and conditions of use of the website.

The layouts of the Renault and VW translated ELF documents are, on the other hand, much more comparable for number of words, layout, contents and names of their titled clauses. Of the two, however, the VW ELF document is the one which best reflects the awareness on the part of the drafter of the original German document of the need to internationalise the source text by adapting it to the conventions of this highly standardised legal format. At a lower level of analysis, this is also reflected in the lack of loan translations (calques) in the names of the VW document's clauses, as opposed to the four titles of the Fiat ELF translated document that, being all literal translations of the Italian source text, do anything but follow the titling conventions of the standard clauses of Terms and conditions in English.

Some degree of adaptation of the source text to its international business purpose emerges also from the Renault ELF translated document at the level of both contents and names of clauses. The French source text - a document titled "Informations légales" and accessible via the "Info légales" button in the Renault international website in French (www.renault.com/fr) - is in fact a significantly different and shorter version of the French document bearing the same title to be found in the national French website (www.renault.fr). This longer version of the "Informations légales" is, like the Fiat Italian document serving as source text for the ELF translation, nearly completely devoted to privacy issues and local commercial/financial information, which in the shorter version serving as source text for the ELF translation were rightly considered not to be relevant for the international market and duly expunged. As for the names of the clauses, only two out of the total 12 clauses of the Renault ELF translated document have names reflecting a literal translation of the French source text and not the conventional formulas of this legal format (Préambule/Overview; Publication et Hébergement/Publication and hosting). 


\section{ELF vs. ENL documents: Layout/Contents}

The second step was to contrast, in each of the three Fiat, Renault and VW subcorpora, the layouts/contents of the ENL Terms and conditions among themselves and with the respective ELF translated document. The aims were to find the similarities/differences (1) across the ENL documents, all drafted in national legislations rooted in common law, and (2) between the ENL non-translated documents and the respective ELF Terms and conditions, translated from source texts drafted in legal systems rooted in civil law (Italian, French and German).

In the 8 Fiat websites (Table 3), the 8 ENL non-translated Terms and conditions generally show a lower degree of homogeneity in both content and layout not only in comparison to the ELF translated document in the international Fiat website - which is hardly surprising given that the original Italian source text was nowhere near being an internationalised document — but also in a cross-national comparison among the 8 different documents. Such a lack of standardisation emerges not only from the very different lengths of the documents but also from the names of the buttons to access the Terms and conditions - which, in the case of the US Fiat site, are two ("Copyright" and "Legal Safety and Trademark Information") instead of one - as well as in the titles, layout and names of the relevant clauses of the documents. The only exception is provided by the document in the Fiat UK website and its slightly shorter version in the Fiat Ireland website, which are nearly identical, apart from the different names of the buttons for accessing the documents ("Legal" in the UK site vs. "Terms and conditions" in the Irish one) and the removal in the Irish document of some sections of the UK one concerning information about Fiat's registered offices and the exclusion of liability for withdrawing the site's services. However, one feature that is common to all the Fiat ENL non-translated documents is that, unlike the ELF translated document, they all provide some legal information on the use of the website.

In the Renault subcorpus, notwithstanding the apparent effort of internationalising the source text of the ELF translation in the Renault international site (see Section 4), the six different ENL non-translated Terms and conditions display an even greater variety than their counterparts in the Fiat ENL websites as regards title and layout, as well as names and length of their clauses (Table 4). For example, the "Security" clause of the Indian ENL document contains only a fraction of the information of the same clause in the Renault ELF document and has consequently been removed from the subcorpus because it consisted of only one short paragraph on the protection of users' information. As in the case of the Fiat ENL websites, the highest degree of similarity is displayed by the Renault Irish and UK documents.

Compared to both the Fiat and Renault subcorpora, the ENL nontranslated documents of the Volkswagen subcorpus display a higher 
degree of homogeneity in terms of general layout/contents and clauses' names not only among themselves but also in comparison with the VW ELF translated document (Table 5). Such a greater homogeneity, which incidentally seems to be a feature of the Terms and conditions of other German multinational corporations, ${ }^{3}$ could in part be due to the more internationalised nature of the original German source text and the resulting ELF translated text of the VW international site, which consequently could have provided at least a rough template for the ENL documents.

One striking feature providing homogeneity to the VW websites is that, with the exception of New Zealand and UK, they all display right in the homepage a text called "Note" containing a disclaimer about the specifications of the car models contained in the site. However, though both the content of the Note and its unusual location follow the layout of the ELF international website. The Note's length, contents and wording vary from site to site, with the exception of Australia and India, where the wording of the Note is the same. The longest Note is in the South African site, where it mentions also the fuel consumption and $\mathrm{CO} 2$ emission values for the different car models, whereas this same information is contained in the main Terms and conditions of the international (ELF) and Indian sites. In the latter, an identical text to that of the Note is also repeated in the initial paragraph (called "Disclaimer") of the Terms and conditions, which are in turn identical to those contained in the ELF translated document embedded in the VW international site right from the very first clause, that is, a disclaimer on fuel consumption making reference to an EU directive ("Notice in accordance with Directive 1999/94/EC regarding fuel consumption and CO2 emissions"), which is rather puzzling given that India is not in the EU.

On the other hand, the VW UK and Ireland ENL Terms and conditions, which in the Fiat and Renault subcorpora were the ones displaying more similarities, have a completely different layout, with the Irish "Terms of use" being structured in numbered untitled paragraphs vs. the UK "Terms and Conditions for Internet Use" being organised in 8 numbered and titled clauses, the second of which is a "Privacy statement" that in the Irish website is in fact accessible via a specific Privacy button.

Finally, the VW US "Terms and Conditions" is a completely different document from not only the ELF translated one (nearly twice as long) but also all the other VW ENL disclaimers, featuring, as it does, as many as 12 unnumbered clauses whose titles (and contents) can be very detailed in scope (e.g., "Limit to Users Modification of These Terms and Conditions", "Airbags", "Claims of Copyright Violations and Agent for Notice"). 


\section{ELF vs. ENL documents: Some language features}

The third step in the analysis was to contrast, across the three subcorpora and in all the ENL non-translated documents as well as in the three ELF translated ones, some features characterising the language of the legal documents at the lower levels of lexis and phraseology (see Gotti, 2011, pp. 32-33; Sours, 2012, pp. 362-365; Williams, 2007, pp. 32-33). Within the general aim of finding similarities/differences between non-translated (ENL) vs. translated (ELF) Terms and conditions, the hypothesis was that the translated documents would display to a lesser degree linguistic features characterising ENL legal varieties. The investigated features, all found in the ENL documents, were: the archaic adverbial expressions thereof, therein, thereupon, thereon, thereto, herein, hereto, hereby, hereunder, howsoever and whereby characterising general legal English; and two multiword prepositional structures typical of disclaimers of liability and/or warranty, that is, including but not limited to and arising out of or in connection with.

A first result concerning the formulaic adverbial expressions was that only two occurrences of whereby were found in the ELF translated documents, one in the Fiat and the other in the VW translations:

Said consent may be revoked at any time, whereby the ability to use the service in question is lost (Fiat international, my emphasis);

In cases of minor negligence Volkswagen AG accepts liability only in the event of infringement of an essential obligation, whereby the sum of any related claims for damages is limited to the extent of the foreseeable loss (Volkswagen international, my emphasis).

As shown in Table 6, however, the use of the adverbial expressions listed above came out to be far from homogenous across the ENL nontranslated documents, suggesting that this formulaic language should also be correlated to the idiosyncratic use of language of individual drafters. For example, the frequency of these expressions in the Fiat India document is very high (10) when correlated to the number of types of the document (189) (Table 1), which is much lower than the number of types not only of the VW Ireland document (330) displaying the same total number of occurrences (10), but also of the Fiat Ireland document (333), where only one occurrence of such expressions could be found. By the same token, the total of 10 occurrences in the VW Ireland document (330 types) indicates a nearly double frequency of occurrence of these adverbials in comparison to the VW UK document, where the number of types (342) is only slightly higher though the occurrences are only 7, and an even higher frequency when compared to the VW US document (only 8 occurrences in as many as 607 types). 
Even more strikingly, in the three ELF translated documents no instance whatsoever was found of the two investigated language features that are specific to disclaimers of liability. As regards including but not limited to, across the ENL non-translated documents an impressive total of 26 occurrences ${ }^{4}$ was found of the expression as such (13) and of its three variants including (but not limited to), including and without limitation to and including without limitation to (13). In most cases, they were used to disclaim liability concerning:

(1) the accuracy of the information contained in the site (products, prices, car services, incentive programs, images etc.), sometimes in combination with the fixed expression as is, for example:

The information, services, products and materials published on this web site, including without limitation, text, graphics and links are provided on an "as is" basis (Renault South Africa, my emphasis);

(2) the right to make changes to the site (or to the Terms and conditions) at any time without notice, for example:

Chrysler Canada Inc. reserves the right to make changes at any time, without notice or obligation, in the information contained on this Site, including and without limitation to prices, incentive programs, specifications, equipment, colours, materials and to change or discontinue models (my emphasis);

(3) damages of any kind arising from the use of the site (e.g., loss of data or programs, financial loss) or from hyperlinking, for example:

You visit the site at your own risk. Under no circumstances will RENAULT or any members of its network be held liable for damages, whether direct or indirect, including but not limited to loss, loss of data or programs, or financial loss resulting from access to or use of this site or any of the sites linked to it (except personal injury or death caused by our negligence) (Renault Canada, my emphasis).

In one case (Renault South Africa) the disclaimer of liability also referred to the possible use of the information of the site as "financial, accounting, tax, legal, investment, consulting or other professional advice or services", and in another (VW Ireland) to the validity of such information only for the authorised VW retailers in Ireland.

Of the 6 cases in which the use of the expression including but not limited to was not in connection to disclaiming liability, 4 were in clauses relating to copyright issues, both in VW sites ( 2 in VW Ireland and 2 in VW US), for example: 
The Website is protected by United States copyright law and international treaty provisions, including, without limitation, the Berne Convention (my emphasis);

one case was an express prohibition:

You will not attempt to interfere with the operation or functionality of this website (including but not limited to) uploading corrupt data or viruses (Fiat UK, my emphasis);

and the remaining one concerned the independence of each section of the Terms and conditions of the others, allowing a court to invalidate a clause of the contract without voiding the entire agreement (often called "Severability" clause):

If any part of this Agreement is determined to be invalid or unenforceable pursuant to applicable law, including, but not limited to, the warranty disclaimers and liability limitations set forth above, then the invalid or unenforceable provision will be deemed superseded by a valid, enforceable provision that most closely matches the intent of the original provision and the remainder of the Agreement shall continue in effect (VW US, my emphasis).

As for the second multiword prepositional structure investigated, that is, arising out of or in connection with - and its variants: arising out of or in any way connected with, arising out of or relating to, arising out of, arising in connection with and due to or arising out of - a total of 15 occurrences $^{5}$ were found across the ENL non-translated documents. Of these, all but three were used in connection with the exclusion/limitation of liability for any losses or damages incurred by using the site:

You agree that Volkswagen Group Australia is not liable to you or anyone else for any loss or damages (including direct, indirect, special or consequential loss) arising out of or in connection with the use of the Website, the use by Volkswagen Group Australia of information provided by you to Volkswagen Group Australia through the Website, or any loss or damage which may arise should you be unable to access the Website, for whatever reason and however arising, including negligence (my emphasis).

The remaining three (Fiat India, Renault South Africa and VW US) occurred in clauses referring to the jurisdiction/applicable law, for example: 
You hereby irrevocably consent to the exclusive jurisdiction and venue of courts in Mumbai, Maharashtra, India in all disputes arising out of or relating to the use of the Fiat website and the information contained therein (Fiat India, my emphasis).

\section{Conclusion}

What seems to emerge from this small-scale exploratory study analysing a small corpus of both translated (ELF) and non-translated (ENL) Terms and conditions embedded in commercial websites is that different national legislations, also based in common law, construe differently, both content-wise and linguistically, even a standard international legal format such as this. From a comparison of the ELF translated Terms and conditions in the three international sites of Fiat, Renault and VW, the three translations from respectively Italian, French and German were found to display a very low level of homogeneity, ultimately indicating that each translation reflects to a greater or lesser extent the specific legal reality that produced its respective source text. In particular, the differences in the layout and contents of the three ELF translated documents wereg correlated to the different relevance given to the clauses excluding/limiting liability as for the accuracy of the contents of the site, which in fact are the norm in international contract practice. Given that the internationalisation of a legal document to be translated in English requires right from the drafting stage an international lawyer able to provide "a legal perspective that transcends the national and cultural perspective of the client" (Drolshammer and Vogt, 2003, pp. 3-8), the differences among the three ELF documents had less to do with the translation approach adopted by their respective translators and more with the drafting stage of the source texts, involving a different degree of adaptation of the nationally-based legal document in, respectively, Italian, French and German, to make it more "efficient" and "appropriate" to the international business purpose it was intended for (see Ehrenreich, 2009, pp. 137-139). Such a degree of internationalisation was highest in the VW ELF translation and lowest in the Fiat one, a finding that corroborates the more general lack in Italian websites of documents stating the Terms and conditions of use of the website which was found in a previous study (Magris \& Scarpa, 2013).

From a comparison of the ELF translated and the ENL nontranslated documents in each subcorpus, the VW Terms and conditions displayed the highest homogeneity, which seems to suggest that an ELF translation resulting from an internationalised source text can indeed provide a template even for the ENL national sites. No correlation was found, however, between the different degree of adaptation of the Fiat and Renault ELF translated documents and an accordingly different degree of homogeneity among the ENL non-translated documents of each 
car manufacturer. A comparison in each of the two subcorpora of the ENL Terms and conditions from different national sites highlighted in fact a great variety of formats and contents, with the possible exception of the UK and Ireland sites of both Fiat and Renault. This fundamental lack of homogeneity suggests that the ELF translations in the international sites of Fiat and Renault were both deemed inappropriate as a template for the respective ENL national sites, notwithstanding the higher degree of internationalisation of the Renault French source text.

Irrespective of the degree of homogeneity of ELF and ENL documents in each subcorpus, at the lower levels of lexis and phraseology the ENL non-translated documents from all three subcorpora were found to display some linguistic features characterising English legal language in general and English disclaimers of liability in particular that in fact were nearly totally absent in the three ELF translated documents. This finding is in line with a sociological differentiation that has been conceptualised in research on intralingual variation between ELF and ENL (see Jenkins, 2007, p. 73), that is, the distinction between languagefocussed and content-focussed perspectives on English, with the second concentrating much more on what is being said rather than how it is said and characterising professional groups of ELF speakers.

At a more general level, the results of the study seem to contradict to some extent McDonough's (2004, pp. 99-100) contention that translations in websites of two countries of origin having only minimal linguistic/cultural differences may not require changes or adaptations and to corroborate instead previous findings (Magris \& Scarpa, 2013) concerning the great variety of formats among both ENL and ELF disclaimers. The reformulation following the recontextualisation of even a standard format such as that of the Terms and conditions of use of a website is also in line with the findings of other scholars for other comparable legal models, such as the UNCITRAL document for international commercial arbitration, where the adaptation to different national realities has taken place even though the Model Law had been created with the purpose of achieving the highest degree of harmonisation (Gotti, 2007, 2009). These international legal models should consequently be considered as "globally-relevant STs" (Adab, 1998, p. 224), that is, flexible text formats that have been adopted by most countries but at the same time allow for local socio-cultural aspects to influence the construction of legal discourse.

\section{References}

Adab, B. (1998). Torwards a more systematic approach to the translation of advertising texts. In A. Beeby, D. Esinger, \& M. Presas (Eds.), Investigating translation (pp. 223-234). Amsterdam: John Benjamins. 
Drolshammer, J. V., \& Vogt, N. P. (2003). English as the language of law?: An essay on the legal lingua franca of a shrinking world. Zurich: Schulthess.

Ehrenreich, S. (2009). English as lingua franca in multinational corporations: Exploring business communities in practice. In A. Mauranen \& E. Ranta (Eds.), English as a lingua franca: Studies and findings (pp. 126-151). Newcastle upon Tyne: Cambridge Scholars.

Gotti, M. (2007). Legal discourse in multilingual and multicultural settings. In K. Kredens \& S. Goźdź-Roszkowski (Eds.), Language and the law: International outlooks (pp. 21-33). Frankfurt: Peter Lang.

Gotti, M. (2009). Globalizing trends in legal discourse. In F. Olsen, R. A. Lorz, \& D. Stein (Eds.), Translation issues in language and law (pp. 55-75). Basingstoke: Palgrave MacMillan.

Gotti, M. (2011). Investigating specialized discourse (new ed.). Bern: Peter Lang.

Jenkins, J. (2007). English as a lingua franca: Attitude and identity. Oxford: Oxford University Press.

Jiménez-Crespo, M. A. (2011). To adapt or not to adapt in web localization: A contrastive genre-based study of original and localized legal sections in corporate websites. Jostrans: The Journal of Specialised Translation, 15, 2 27.

McDonough, J. (2004). Hiding difference: On the localization of websites. The Translator, 12(1), 85-103.

Magris, M., \& Scarpa, F. (2013). Ähnlich, aber doch anders?: Eine kontrastive Analyse der Textsorte Disclaimer auf Webseiten anhand von Originaltexten und Übersetzungen. In M. Krein-Kühle, U. Wienen, \& R. Krüger (Eds.), Kölner Konferenz zur Fachtextübersetzung (2010)/Cologne Conference on Specialized Translation (2010) (pp. 135-150). Frankfurt: Peter Lang.

Sours, P. (2012). Legal grammar handbook. In A. Riley \& P. Sours (Eds.), Legal English and the common law (with legal grammar handbook by Patricia Sours) (pp. 351-477, 2nd ed.). Padova: CEDAM/Wolters Kluwer Italia Srl.

Williams, C. (2007). Tradition and change in legal English: Verbal constructions in prescriptive texts (2nd ed.). Bern: Peter Lang. 
Table 1: Fiat, Renault and Volkswagen ELF and ENL subcorpora

\begin{tabular}{|c|c|c|}
\hline & Tokens & Types \\
\hline ELF subcorpus (translations) & 4,129 & 980 \\
\hline ENL subcorpus & 16,932 & 1,890 \\
\hline \multicolumn{3}{|l|}{ FIAT } \\
\hline International (Fiat.com) & 282 & 154 \\
\hline Australia (fiatcommercial.com.au) & 155 & 90 \\
\hline Australia (Chrysler.com.au) & 45 & 39 \\
\hline Canada (Chrysler.ca/en) & 1,036 & 389 \\
\hline India (fiat-india.com) & 400 & 189 \\
\hline Ireland (fiat.ie) & 1,039 & 333 \\
\hline South Africa (fiat.co.za) & 66 & 46 \\
\hline United Kingdom (fiat.co.uk) & 1,430 & 444 \\
\hline $\begin{array}{l}\text { United States (fiatusa.com/en) } \\
\text { (Copyright) }\end{array}$ & 343 & 150 \\
\hline $\begin{array}{l}\text { United States (fiatusa.com/en) } \\
\text { (Legal, safety etc.) }\end{array}$ & 65 & 54 \\
\hline TOTAL & 4,861 & 908 \\
\hline \multicolumn{3}{|l|}{ RENAULT } \\
\hline International (Renault.com/en) & 2,634 & 681 \\
\hline Australia (Renault.com.au) & 426 & 182 \\
\hline Canada (renaultcanada.com) & 289 & 135 \\
\hline
\end{tabular}




\begin{tabular}{|c|c|c|}
\hline India (Renault.co.in) & 176 & 108 \\
\hline Ireland (renault.ie) & 753 & 263 \\
\hline South Africa (Renault.co.za) & 814 & 298 \\
\hline United Kingdom (Renault.co.uk) & 1,278 & 429 \\
\hline TOTAL & 6,370 & 1,143 \\
\hline \multicolumn{3}{|l|}{ VOLKSWAGEN } \\
\hline International (en.volkswagen.com) & 1,213 & 417 \\
\hline Australia (volkswagen.com.au) & 1,033 & 279 \\
\hline Canada (vw.ca) & 745 & 261 \\
\hline India (Volkswagen.co.in) & 1,406 & 434 \\
\hline Ireland (volkswagen.ie) & 881 & 330 \\
\hline $\begin{array}{l}\text { New Zealand (volkswagen.co.nz) } \\
\text { (Terms of Use) }\end{array}$ & 140 & 89 \\
\hline $\begin{array}{l}\text { New Zealand (volkswagen.co.nz) } \\
\text { (Privacy Policy) }\end{array}$ & 204 & 107 \\
\hline South Africa (vw.co.za) & 1,292 & 385 \\
\hline United Kingdom (volkswagen.co.uk) & 848 & 342 \\
\hline United States (vw.com) & 2,068 & 607 \\
\hline TOTAL & 9,830 & 1,350 \\
\hline GRAND TOTAL & 21,061 & 2,153 \\
\hline
\end{tabular}


Table 2: Layout of the legal document containing the disclaimer in the Fiat, Renault and Volkswagen international ELF websites

\begin{tabular}{|c|c|c|c|}
\hline & $\begin{array}{l}\text { FIAT International } \\
\text { ( } 282 \text { words) }\end{array}$ & $\begin{array}{l}\text { RENAULT International } \\
\text { (2,634 words) }\end{array}$ & $\begin{array}{l}\text { VOLKSWAGEN International } \\
\text { (1,213 words) }\end{array}$ \\
\hline & & & Additional legal note in the Homepage \\
\hline $\begin{array}{l}\text { Name Button containing } \\
\text { Legal Document }\end{array}$ & Web Privacy & Legal information & Legal statement \\
\hline Title Legal Document & Privacy - Web Privacy Policy & "Legal information \& Contributions. Legal Information" & Legal Details \\
\hline Relevant Clauses & $\begin{array}{l}\text { General introduction } \\
\text { Connection to third-party sites } \\
\text { Behaviour inconsistent with } \\
\text { the policy (Loyalty) } \\
\text { Policy change }\end{array}$ & $\begin{array}{l}\text { Overview } \\
\text { Art.1 Publication and hosting } \\
\text { Art.2 Intellectual Property Rights (Copyright and design right; Registered trademarks) } \\
\text { Art.4 Site access } \\
\text { Art.5 Use of forums, blogs, discussions (Using the site; Moderation; User obligations; } \\
\text { Obligations of www.renault.com; Intellectual ownership of messages; Liability) } \\
\text { Art.7 Hypertexts Links } \\
\text { Art.8 Security } \\
\text { Art.9 Responsibility } \\
\text { Art.10 Suspension or interruption of access } \\
\text { Art.11 Dealer network } \\
\text { Art.12 Applicable law } \\
\text { Art.13 Update of CAU }\end{array}$ & $\begin{array}{l}\text { Conditions of Use } \\
\text { 1. Notice in accordance with Directive 1999/94/EC } \\
\text { regarding fuel consumption and CO2 emissions } \\
\text { 2. Delivery of information services and related guarantees } \\
\text { 3. Special information services } \\
\text { 4. Services provided by partners } \\
\text { 5. Links to third-party websites } \\
\text { 6. Permissible use of services } \\
\text { 8. Links to websites of Volkswagen AG } \\
\text { 9. Liability } \\
\text { 11. Changes to the scope of performance and to the } \\
\text { Conditions of Use } \\
\text { 12. Choice of law }\end{array}$ \\
\hline
\end{tabular}


Table 3: Layout of the legal documents containing the disclaimer in the Fiat websites in English

\begin{tabular}{|c|c|c|c|c|c|c|c|c|c|}
\hline Fiat & $\begin{array}{l}\text { International } \\
(282)\end{array}$ & $\begin{array}{l}\text { Australia } \\
\text { (FiatCommercial) } \\
\text { (155) }\end{array}$ & $\begin{array}{l}\text { Australia } \\
\text { (Fiat500/Chrysler) } \\
\text { (45) }\end{array}$ & $\begin{array}{l}\text { Canada } \\
(1,036)\end{array}$ & $\begin{array}{l}\text { India } \\
(400)\end{array}$ & $\begin{array}{l}\text { Ireland } \\
(1,039)\end{array}$ & $\begin{array}{l}\text { South Africa } \\
\text { (66) }\end{array}$ & $\begin{array}{l}\text { United Kingdom } \\
(1,430)\end{array}$ & $\begin{array}{l}\text { United States } \\
(418)\end{array}$ \\
\hline $\begin{array}{l}\text { Name Button/s } \\
\text { containing Legal } \\
\text { Document }\end{array}$ & Web Privacy & $\begin{array}{l}\text { Terms and Privacy } \\
\text { Policy }\end{array}$ & $\begin{array}{l}\text { Legal, Safety and } \\
\text { Trademark } \\
\text { information }\end{array}$ & $\begin{array}{l}\text { Trademarks \& } \\
\text { Copyrights }\end{array}$ & Privacy Policy & $\begin{array}{l}\text { Terms and } \\
\text { conditions }\end{array}$ & Disclaimer & Legal & $\begin{array}{l}\text { 1) Copyright } \\
\text { 2) Legal, Safety } \\
\text { and Trademark } \\
\text { information }\end{array}$ \\
\hline $\begin{array}{l}\text { Additional legal } \\
\text { buttons }\end{array}$ & & & Privacy Policy & Privacy Policy & & Privacy Policy & & $\begin{array}{l}\text { 1) Privacy } \\
\text { 2) Cookies }\end{array}$ & Privacy \\
\hline $\begin{array}{l}\text { Title Legal } \\
\text { Document }\end{array}$ & $\begin{array}{l}\text { Privacy - } \\
\text { Web Privacy } \\
\text { Policy }\end{array}$ & Disclaimer & & Disclaimer Policy & $\begin{array}{l}\text { Disclaimer of } \\
\text { Liability and } \\
\text { Reservation of } \\
\text { Rights }\end{array}$ & $\begin{array}{l}\text { Terms and } \\
\text { Conditions }\end{array}$ & Disclaimer & $\begin{array}{l}\text { Terms and } \\
\text { conditions }\end{array}$ & $\begin{array}{l}\text { Chrysler Group } \\
\text { LLC Digital } \\
\text { Millennium } \\
\text { Copyright Act } \\
\text { Policy }\end{array}$ \\
\hline $\begin{array}{l}\text { Relevant } \\
\text { Clauses }\end{array}$ & $\begin{array}{l}\text { General } \\
\text { introduction } \\
\text { Connection to } \\
\text { third-party } \\
\text { sites } \\
\text { Behaviour } \\
\text { inconsistent } \\
\text { with the } \\
\text { policy } \\
\text { (Loyalty) } \\
\text { Policy change }\end{array}$ & $\begin{array}{l}\text { Regarding } \\
\text { Website } \\
\text { Information }\end{array}$ & & $\begin{array}{l}\text { Copyrights } \\
\text { Canadian Market Only } \\
\text { Trademarks } \\
\text { Suggestions And Ideas } \\
\text { Prices and Products } \\
\text { NO WARRANTIES } \\
\text { OR } \\
\text { REPRESENTATIONS } \\
\text { Images } \\
\text { No Licences } \\
\text { Terms and Conditions } \\
\text { Off.Site Pages }\end{array}$ & & $\begin{array}{l}\text { Use/links } \\
\text { Intellectual } \\
\text { Property } \\
\text { Rights/Copyright } \\
\text { DISCLAIMER } \\
\text { Market conditions } \\
\text { Amendments } \\
\text { Law }\end{array}$ & & $\begin{array}{l}\text { Information } \\
\text { about us } \\
\text { Use/Links } \\
\text { Intellectual } \\
\text { Property } \\
\text { Rights/Copyrigh } \\
\mathrm{t} \\
\text { Disclaimer } \\
\text { Market } \\
\text { conditions } \\
\text { Amendments } \\
\text { Law }\end{array}$ & \\
\hline
\end{tabular}


Table 4: Layout of the legal documents containing the disclaimer in the Renault websites in English

\begin{tabular}{|c|c|c|c|c|c|c|c|}
\hline Renault & $\begin{array}{l}\text { International } \\
(2,634)\end{array}$ & $\begin{array}{l}\text { Australia } \\
\text { (426) }\end{array}$ & $\begin{array}{l}\text { Canada } \\
(289)\end{array}$ & $\begin{array}{l}\text { India } \\
(176)\end{array}$ & $\begin{array}{l}\text { Ireland } \\
(753)\end{array}$ & $\begin{array}{l}\text { South Africa } \\
(814)\end{array}$ & $\begin{array}{l}\text { United Kingdom } \\
(1,278)\end{array}$ \\
\hline $\begin{array}{l}\text { Name of Button } \\
\text { containing Legal } \\
\text { Document }\end{array}$ & Legal information & Legal Info & Legal considerations & $\begin{array}{l}\text { Legal } \\
\text { information }\end{array}$ & Legal information & Legal Info & Legal info \\
\hline Additional legal buttons & & & & & & & Personal Data Protection \\
\hline $\begin{array}{l}\text { Title of Legal } \\
\text { Document }\end{array}$ & $\begin{array}{l}\text { "Legal information \& Contributions. } \\
\text { Legal Information" }\end{array}$ & $\begin{array}{l}\text { "Privacy } \\
\text { Policy" }\end{array}$ & "Legal considerations" & & "Legal information" & $\begin{array}{l}\text { "Legal \& Copyright } \\
\text { Notices. Disclaimer" }\end{array}$ & \\
\hline Relevant Clauses & $\begin{array}{l}\text { Overview } \\
\text { Publication and hosting } \\
\text { Intellectual Property Rights (Copyright } \\
\text { and design right; Registered trademarks) } \\
\text { Site access } \\
\text { Use of forums, blogs, discussions } \\
\text { Hypertexts Links } \\
\text { Security } \\
\text { Responsibility } \\
\text { Suspension or interruption of access } \\
\text { Dealer network } \\
\text { Applicable law } \\
\text { Update of CAU }\end{array}$ & $\begin{array}{l}\text { Copyright } \\
\text { Renault } \\
\text { Website }\end{array}$ & $\begin{array}{l}\text { General Information; } \\
\text { Intellectual Property Rights } \\
\text { Links to Other Sites } \\
\text { Products and Services } \\
\text { Information }\end{array}$ & $\begin{array}{l}\text { Links } \\
\text { Disclaimer }\end{array}$ & $\begin{array}{l}\text { Terms and conditions for } \\
\text { use of this site } \\
\text { Intellectual Property } \\
\text { Rights } \\
\text { Hypertext Links } \\
\text { Limit of Liability } \\
\text { Products and services } \\
\text { Service } \\
\text { Renault Dealer Network } \\
\text { Applicable Law } \\
\text { Updating the Terms and } \\
\text { Conditions }\end{array}$ & $\begin{array}{l}\text { Copyright } \\
\text { Liability Disclaimer } \\
\text { Limitation of } \\
\text { Liability } \\
\text { Professional } \\
\text { Information } \\
\text { Applicable Law } \\
\text { Violation and } \\
\text { Waiver }\end{array}$ & $\begin{array}{l}\text { Terms and conditions for } \\
\text { use of this site } \\
\text { Intellectual Property } \\
\text { Rights } \\
\text { Passwords and Access } \\
\text { Codes } \\
\text { Renault Community - } \\
\text { forum rules } \\
\text { Renault Social Media } \\
\text { Hypertext Links } \\
\text { Limit of Liability } \\
\text { Products and services } \\
\text { Services } \\
\text { Renault Dealer Network } \\
\text { Applicable Law } \\
\text { Updating the Terms and } \\
\text { Conditions }\end{array}$ \\
\hline
\end{tabular}


Table 5: Layout of the legal documents containing the disclaimer in the Volkswagen websites in English

\begin{tabular}{|c|c|c|c|c|c|c|c|c|c|}
\hline Volkswagen & $\begin{array}{l}\text { International } \\
(1,213)\end{array}$ & $\begin{array}{l}\text { Australia } \\
(1,033)\end{array}$ & $\begin{array}{l}\text { Canada } \\
\text { (745) }\end{array}$ & $\begin{array}{l}\text { India } \\
(1,406)\end{array}$ & $\begin{array}{l}\text { Ireland } \\
(881)\end{array}$ & $\begin{array}{l}\text { New } \\
\text { Zealand } \\
(344)\end{array}$ & $\begin{array}{l}\text { South Africa } \\
(1,292)\end{array}$ & $\begin{array}{l}\text { UK } \\
(848)\end{array}$ & $\begin{array}{l}\text { US } \\
(2,068)\end{array}$ \\
\hline & $\begin{array}{l}\text { Additional legal note } \\
\text { in the Homepage }\end{array}$ & $\begin{array}{l}\text { Additional } \\
\text { legal note in } \\
\text { the Homepage }\end{array}$ & $\begin{array}{l}\text { Additional } \\
\text { legal note in the } \\
\text { Homepage }\end{array}$ & $\begin{array}{l}\text { Additional legal note in the } \\
\text { Homepage }\end{array}$ & $\begin{array}{l}\text { Additional } \\
\text { legal note in } \\
\text { the Homepage }\end{array}$ & & $\begin{array}{l}\text { Additional legal } \\
\text { note in the } \\
\text { Homepage }\end{array}$ & & $\begin{array}{l}\text { Additional legal note in } \\
\text { the Homepage }\end{array}$ \\
\hline $\begin{array}{l}\text { Name Button/s } \\
\text { containing Legal } \\
\text { Document }\end{array}$ & Legal statement & Legal & Legal & Legal Statement & Terms of use & $\begin{array}{l}\text { 1) Terms } \\
\text { of Use } \\
\text { 2) } \\
\text { Privacy } \\
\text { Policy }\end{array}$ & Legal & Legal policy & Terms \\
\hline $\begin{array}{l}\text { Additional legal } \\
\text { buttons }\end{array}$ & & Privacy Policy & & & Privacy & & & Cookie policy & Privacy \\
\hline $\begin{array}{l}\text { Title Legal } \\
\text { Document/s }\end{array}$ & Legal Details. & Legal & Legal Details & $\begin{array}{l}\text { Conditions of use of this } \\
\text { website }\end{array}$ & Terms of use & $\begin{array}{l}\text { 1) Terms } \\
\text { of Use } \\
\text { 2) } \\
\text { Privacy } \\
\text { Policy }\end{array}$ & $\begin{array}{l}\text { Legal Notice. } \\
\text { Terms and } \\
\text { Conditions for } \\
\text { Website Use }\end{array}$ & $\begin{array}{l}\text { Terms and } \\
\text { Conditions for } \\
\text { Internet Use }\end{array}$ & Terms and Conditions \\
\hline Relevant Clauses & $\begin{array}{l}\text { Conditions of Use } \\
\text { 1. Notice in } \\
\text { accordance with } \\
\text { Directive etc. } \\
\text { 2. Delivery of } \\
\text { information services } \\
\text { and related guarantees } \\
\text { 3. Special information } \\
\text { services }\end{array}$ & & $\begin{array}{l}\text { Q\&A } \\
\text { Disclaimer } \\
\text { Intellectual } \\
\text { Property Rights }\end{array}$ & $\begin{array}{l}\text { 1) Notice in accordance } \\
\text { with Directive 1999/94/EC } \\
\text { regarding fuel consumption } \\
\text { and CO2 emissions }\end{array}$ & & & $\begin{array}{l}\text { 1) General } \\
\text { 3) Product } \\
\text { Specification } \\
\text { 4) Intellectual } \\
\text { Property Rights } \\
\text { 5) Disclaimer and } \\
\text { Liability } \\
\text { 7) Misuse } \\
\text { Statement }\end{array}$ & $\begin{array}{l}\text { 1) General } \\
\text { 3) Product } \\
\text { specification } \\
\text { 4) Pricing } \\
\text { 5) Intellectual } \\
\text { property rights } \\
\text { 6) Disclaimer } \\
\text { and liability } \\
\text { 7) Misuse }\end{array}$ & $\begin{array}{l}\text { Initial Notice } \\
\text { List of Restrictions } \\
\text { Scope of Content } \\
\text { Reservation of Rights } \\
\text { Warranty Disclaimers } \\
\text { Liability Limitations } \\
\text { Links to Third Parties' } \\
\text { Websites }\end{array}$ \\
\hline
\end{tabular}




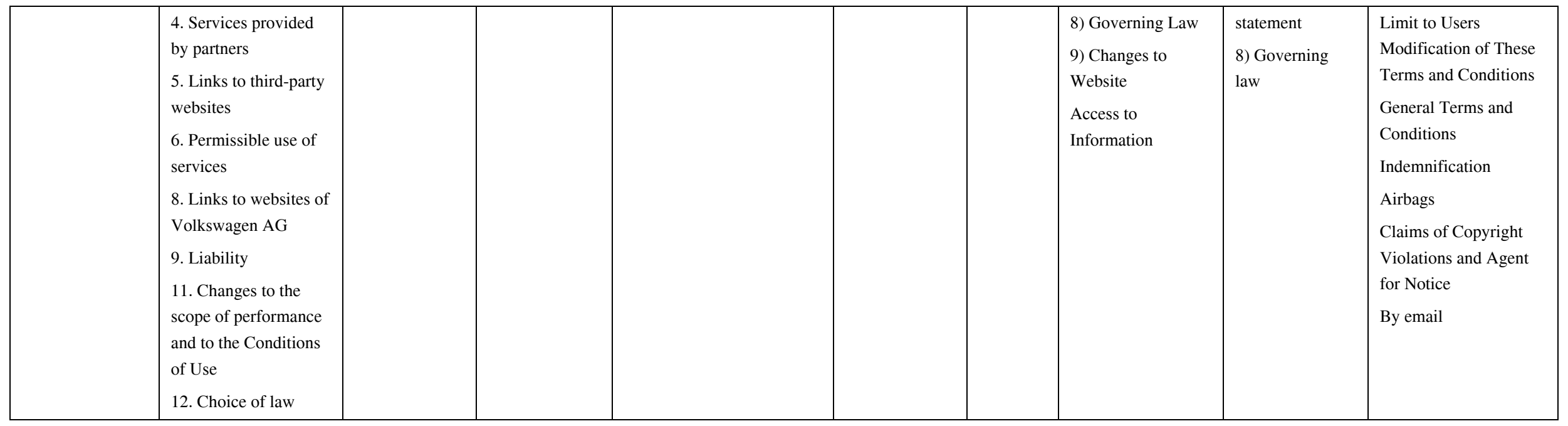


Table 6: Occurrences of legal adverbial expressions in ENL non-translated documents

\begin{tabular}{|c|c|c|c|c|c|c|c|c|c|c|c|c|c|}
\hline & $\begin{array}{l}\text { Fiat Australia } \\
\text { (2) }\end{array}$ & $\begin{array}{l}\text { Fiat India } \\
\quad(10)\end{array}$ & $\begin{array}{l}\text { Fiat Ireland } \\
\text { (1) }\end{array}$ & $\begin{array}{l}\text { Fiat UK } \\
\text { (1) }\end{array}$ & $\begin{array}{l}\text { Renault Ireland } \\
\text { (3) }\end{array}$ & $\begin{array}{l}\text { Renault South Africa } \\
\text { (5) }\end{array}$ & $\begin{array}{l}\text { Renault UK } \\
\text { (2) }\end{array}$ & $\begin{array}{l}\text { VW India } \\
\text { (1) }\end{array}$ & $\begin{array}{l}\text { VW Ireland } \\
\text { (10) }\end{array}$ & $\begin{array}{l}\text { VW South Africa } \\
\text { (2) }\end{array}$ & $\begin{array}{l}\text { VW UK } \\
\text { (7) }\end{array}$ & $\begin{array}{c}\text { VW US } \\
(8)\end{array}$ & $\begin{array}{r}\text { TOT } \\
(51)\end{array}$ \\
\hline Thereof & & 1 & & & & 2 & & & 4 & & 1 & 4 & 12 \\
\hline Hereby & & 3 & & & & 1 & & & 3 & 1 & 3 & & 11 \\
\hline Whatsoever & 1 & 1 & & & 2 & & 2 & & 1 & 1 & 2 & & 10 \\
\hline Herein & 1 & 1 & & & & 1 & & & 1 & & 1 & 1 & 6 \\
\hline Therein & & 3 & & & & & & & & & & & 3 \\
\hline Hereunder & & & & & 1 & & & & & & & 1 & 2 \\
\hline Hereto & & & & & & & & & & & & 1 & 1 \\
\hline Hereunder & & & & & 1 & & & & & & & 1 & 2 \\
\hline Thereupon & & 1 & & & & & & & & & & & 1 \\
\hline Thereon & & & & & & 1 & & & & & & & 1 \\
\hline Thereto & & & & & & & & & 1 & & & & 1 \\
\hline Howsoever & & & 1 & 1 & & & & & & & & & 1 \\
\hline Whereby & & & & & & & & 1 & & & & & 1 \\
\hline
\end{tabular}


1 Where English is an associate official language to Hindi, the constitutionally designated official language of the country.

2 Some examples of websites of disclaimer templates are as follows: Web Guide of the Australian Government ( webguide.gov.au/required-information/disclaimers/); Disclaimer.com (www.disclaimer.de/disclaimer.htm); Sample IT policies, disclaimers and notices of the UK Government ( www.businesslink.gov.uk); Example of a Disclaimer Page in Web Design Essentials (www.avatar.co.nz/resources/web-materials-disclaimer.html); Disclaimer clause in Website Agreement (www.ejurix.com/images/WebsiteAgreement Draft.pdf).

3 See for example the ENL websites of the chemical company BASF in Australia/New Zealand, Canada, India, South Africa, UK/Ireland and US, where the disclaimers have all exactly the same wording as the ELF translation of an original German document.

4 VW US (7), VW Ireland (5), Fiat Canada (4), VW New Zealand (2), Renault South Africa (2), Renault Canada (1), Fiat India (1), Fiat South Africa (1), Fiat UK (1), Renault Ireland (1), Renault UK (1).

5 VW US (3), Fiat India (3), VW Australia (2), Renault South Africa (2), Fiat Canada (1), Renault Ireland (1), Renault UK (1), VW UK (1), Fiat UK (1). 